\title{
Stand up for science
}

\author{
Uncertainty reigns in many domains as the Trump administration takes power. Science is no \\ exception. Federal support for biological research must continue. And scientists must not be \\ silenced by political pressure.
}

We are currently witnessing a powerful example of the biomedical community's ability to rapidly attack a research problem. The Zika virus came to international attention in 2015. Less than two years later, viral pathology and routes of infection are much better characterized, diagnostic tests have been developed, and promising vaccines have moved into human trials. (A PubMed search yields about 100 papers on "Zika virus" before 2016 and over 1,600 since then.) This rapid response has required the combined expertise of many-virologists, neonatologists, neurobiologists, stem cell scientists, epidemiologists, clinicians, and molecular biologists. It has also depended critically upon an arsenal of basic technical know-how that has been developed and refined over the past decades.

Yet many biologists across the US are in a state of uncertainty about what kind of support to expect in coming years. By the time this issue of Nature Methods is in your hands, the Republican Trump administration will hold the presidency and both houses of the US Congress. There has been scant information during the campaign, or since, about how the new administration views biomedical and biological research.

Part of the Republican party platform includes federal spending cuts, but we do not know if these will include biomedical research. However, there is reason to fear that support for embryonic stem cell research and for research that depends on fetal tissue will diminish — the latter is already happening in several states. Both vice-president-elect Mike Pence and Tom Price-the nominee for Secretary of the Department of Health and Human Services (DHHS), who oversees the NIH, the FDA, and the CDC_-are vocal opponents of this work.

Paradoxically, these cuts could result in an increase in funding from the state of California, which has the sixth largest economy worldwide. We have seen a similar situation in the past; when George W. Bush restricted federal funding for embryonic stem cell research to a handful of already derived cell lines, California voters approved an injection of three billion US dollars into stem cell research within the state. But a renewed politicization of this thriving and important work would be a step backwards. Less politically charged items such as the $\$ 755$-million Cancer Moonshot Initiative, opposed by Price, and the discretionary NIH research budget, are also vulnerable.
Speculation regarding biological research is not as dire as for climate science. In addition to Trump's own statements pooh-poohing the evidence for climate change, several key players surrounding him deny climate change or that human activity has contributed to it. In an unsettling development, the Trump transition team requested a list of names of Department of Energy (DOE) employees who had done work related to climate change. The DOE refused to provide this list and has recently released policy intended to protect its researchers-including federal scientists, contractors, and recipients of its fundsfrom political interference.

This brings to mind the situation in Canada during the Harper administration, which sought to block communication between federal scientists and the public, especially on controversial topics relating to conservation and the environment. When the Trudeau government won power last year, restrictions on speaking to the press were removed. Canadian federal scientists, who are unionized, have gone a step further, negotiating contracts in which they are explicitly free to speak about their science to the press and the public without prior government approval. The US DOE policy, though an excellent development, must be respected by the Trump administration. Whether that will happen remains to be seen.

Although the Trump team reportedly repudiated its own request for the DOE list, scientists must be wary in the years to come of attempts to prevent scientific information from reaching the press and the US public. We have seen such attempts before, during the George W. Bush administration. They will not necessarily be obvious; as in Canada, they may come in the form of draconian procedures that delay communication with the press for so long that such communication becomes worthless. Or they may come in the form of intimidating researchers, as in the recent furor over work that requires fetal tissue.

If the US wants to remain a leader in biomedical research, the incoming government will need to keep funding it (including basic research) over the long term. And in all fields, scientists must be able to speak freely about their work if science is to be vigorous, the public informed, and policy decisions based on knowledge rather than ideology. The scientific community is watching and waiting. 